\title{
An Up-scalable, Infiltration-Based Approach for Improving the Durability of Ni/YSZ Electrodes for Solid Oxide Cells
}

\author{
Tong, Xiaofeng; Hendriksen, Peter Vang; Hauch, Anne; Sun, Xiufu; Chen, Ming
}

Published in:

Journal of the Electrochemical Society

Link to article, DOI:

$10.1149 / 1945-7111 / a b 6 f 5 c$

Publication date:

2020

Document Version

Peer reviewed version

Link back to DTU Orbit

Citation (APA):

Tong, X., Hendriksen, P. V., Hauch, A., Sun, X., \& Chen, M. (2020). An Up-scalable, Infiltration-Based Approach for Improving the Durability of Ni/YSZ Electrodes for Solid Oxide Cells. Journal of the Electrochemical Society, 167(2), [024519]. https://doi.org/10.1149/1945-7111/ab6f5c

\section{General rights}

Copyright and moral rights for the publications made accessible in the public portal are retained by the authors and/or other copyright owners and it is a condition of accessing publications that users recognise and abide by the legal requirements associated with these rights.

- Users may download and print one copy of any publication from the public portal for the purpose of private study or research.

- You may not further distribute the material or use it for any profit-making activity or commercial gain

- You may freely distribute the URL identifying the publication in the public portal 


\title{
An Up-scalable, Infiltration-Based Approach for Improving the Durability of Ni/YSZ Electrodes for Solid Oxide Cells
}

Xiaofeng Tong, Peter Vang Hendriksen*, Anne Hauch, Xiufu Sun, Ming Chen ${ }^{2}$

Department of Energy Conversion and Storage, Technical University of Denmark, Roskilde 4000, Denmark

*Electrochemical Society Member.

E-mail:minc@dtu.dk

\begin{abstract}
In solid oxide electrolysis cells (SOECs), considerable degradation of the Ni/YSZ electrode during long-term electrolysis operation at high current densities ( $-1 \mathrm{~A} \mathrm{~cm}^{-2}$ or above) has been an ongoing challenge. In this work we report on a method alleviating the problem based on infiltrating nano-sized electrocatalysts into the Ni/YSZ electrode of a full cell after it has been reduced in a "one-atmosphere-reduction" process. The performance and durability of infiltrated and non-infiltrated cells are evaluated at full test-cell size of $4 \times 4 \mathrm{~cm}^{2}$ level. The infiltrated cell exhibits significantly enhanced durability when operated for steam electrolysis at $750{ }^{\circ} \mathrm{C}$ under high current densities, with cell voltage degradation rates of $0.028 \mathrm{~V} \mathrm{kh}^{-1}\left(2.0 \% \mathrm{kh}^{-1}\right)$ for 800 $\mathrm{h}$ at $-1.25 \mathrm{~A} \mathrm{~cm}^{-2}$ and $0.010 \mathrm{~V} \mathrm{kh}^{-1}\left(0.8 \% \mathrm{kh}^{-1}\right)$ for $300 \mathrm{~h}$ at $-1.00 \mathrm{~A} \mathrm{~cm}^{-2}$. These degradation rates are $\sim 14$ times and $\sim 25$ times smaller than those of the non-infiltrated cell, respectively. The infiltrated cell also shows superior durability to the non-infiltrated cell during reversible operation. These results demonstrate the great potential of boosting the durability of state-of-


the-art Ni/YSZ fuel electrodes for electrolysis operation via this infiltration-based approach.

\section{Introduction}

The rapid growth in electricity generation from solar and wind sources, which is intermittent in character, creates a need for large-scale energy storage. ${ }^{1,2}$ Solid oxide cells (SOCs) have attracted increasing attention in this context, since they can be alternately operated in electrolysis mode (as solid oxide electrolysis cells, SOECs) for storing electricity as hydrogen (or a derived fuel) and in fuel cell mode (as solid oxide fuel cells, SOFCs) for converting these fuels to electricity.

The most commonly used fuel electrode in SOCs is based on Ni/yttria-stabilized zirconia (YSZ) composites, which displays excellent activity both for the hydrogen oxidation reaction (HOR) in fuel cell mode and the hydrogen evolution reaction (HER) in electrolysis mode. However, the Ni/YSZ electrode experiences considerable degradation in electrochemical performance during long-term electrolysis operation, particularly at strong polarization (high current densities). Several different microstructural deteriorations have been reported as contributing to the electrochemical performance degradation, including surface poisoning by impurities, Ni coarsening and migration, destruction of the Ni-YSZ interface, and even formation of $\mathrm{ZrO}_{2}$ nanoparticles on the Ni surface due to the reduction/re-oxidation of YSZ. .- $^{-}$ ${ }^{14}$ Though mixed ionic-electronic conducting (MIEC) oxides, such as $\mathrm{La}_{\mathrm{x}} \mathrm{Sr}_{1-\mathrm{x}} \mathrm{Cr}_{0.5} \mathrm{Mn}_{0.5} \mathrm{O}_{3-\delta}$, ${ }^{15-}$ $17 \mathrm{La}_{0.2} \mathrm{Sr}_{0.8} \mathrm{TiO}_{3+\delta},{ }^{18} \quad \mathrm{La}_{0.4} \mathrm{Sr}_{0.4} \mathrm{Ni}_{0.06} \mathrm{Ti}_{0.94} \mathrm{O}_{3-\delta},{ }^{19} \quad \mathrm{La}_{0.43} \mathrm{Ca}_{0.37} \mathrm{Ni}_{0.06} \mathrm{Ti}_{0.94} \mathrm{O}_{3-\delta},{ }^{20} \quad$ and $\mathrm{Sr}_{2} \mathrm{Fe}_{1.5} \mathrm{Mo}_{0.5} \mathrm{O}_{6-\delta},{ }^{21,22}$ have been explored as alternative fuel electrodes, the catalytic activity 
and electrical conductivity of these MIEC electrodes have not reached the levels observed for the Ni/YSZ electrodes.

Accordingly, it is important to enhance the durability of Ni/YSZ electrodes. Recently, our laboratory has demonstrated that the Ni migration in Ni/YSZ electrode can be effectively mitigated by optimizing the microstructure of the electrode, thus significantly improving cell durability. ${ }^{6}$ More recently, our laboratory has found that modification of the Ni/YSZ electrode by coating the surface with nano-sized electrocatalysts via infiltration is an effective method to enhance the cell performance as well as the cell durability. ${ }^{12,23}$ For example, an infiltration modification has been carried out on a state-of-the-art SOC; Ni/YSZ support | Ni/YSZ fuel electrode | YSZ electrolyte | gadolinium-doped ceria (CGO) barrier layer | strontium and iron co-doped lanthanum cobaltite (LSCF)/CGO oxygen electrode, which reduced the degradation rate during steam electrolysis at $800{ }^{\circ} \mathrm{C}$ from $0.699 \mathrm{~V} \mathrm{kh}^{-1}$ to $0.114 \mathrm{~V} \mathrm{kh}^{-1}$ at $-1.25 \mathrm{~A} \mathrm{~cm}^{-2} .{ }^{12}$ To enable a sufficient porosity in the Ni/YSZ structure for infiltration and to avoid the chemical expansion of the CGO barrier layer and decomposition of the LSCF during reduction, the cell was pre-reduced in a "two-atmosphere-reduction", i.e., the $\mathrm{NiO} / \mathrm{YSZ}$ fuel electrode was exposed to reducing atmosphere while the $\mathrm{LSCF} / \mathrm{CGO}$ oxygen electrode was exposed to air (Fig. 1). This was achieved using an in-house built test rig which is well suited for the purpose if only a small number of cells is considered, but not well suited for mass production. A viable route for realizing the infiltration is performing the treatment as a "two-atmosphere-reduction" on stack level after the Ni/YSZ electrode has been reduced during stack-initiation as was done in $\mathrm{ref}^{24}$. In this work, we simplify the aforementioned infiltration method to allow it to be done before stack assembly, but yet in a way that can be upscaled to mass production. Instead of 
doing the treatment in two-atmosphere requiring temporary sealings, the full cell was subjected to reducing conditions. Treatment as a "one-atmosphere-reduction" that can well be carried out during the cooling of the cell after the final sintering step (Fig. 1).

\section{Experimental}

Manufacturing of SOCs. - The fuel-electrode-supported cells used in this work are in size of $5.3 \times 5.3 \mathrm{~cm}^{2}$ and consist of a Ni/YSZ support, a Ni/YSZ fuel electrode, a dense YSZ electrolyte, a CGO barrier layer, and an LSCF/CGO (LSCF: $\mathrm{La}_{0.6} \mathrm{Sr}_{0.4} \mathrm{Co}_{0.2} \mathrm{Fe}_{0.8} \mathrm{O}_{3-\delta}$ ) composite oxygen electrode. A detailed description of the fuel electrode-supported cell fabrication can be found elsewhere. ${ }^{25} \mathrm{~A} 4 \times 4 \mathrm{~cm}^{2}$ strontium-doped lanthanum manganite (LSM) current-collector layer was applied on top of the LSCF/CGO electrode by screen-printing.

Infiltration of SOCs.-The infiltrated cells with CGO modified Ni/YSZ fuel electrodes were prepared after the full cell was reduced. For the applied "one-atmosphere-reduction", conditions including temperature and gas feeds need to be carefully chosen and controlled. In this work, the treatment was carried out in a tubular furnace at $750{ }^{\circ} \mathrm{C}$ in $3.9 \% \mathrm{H}_{2}-93.2 \% \mathrm{~N}_{2}-$ $2.9 \% \mathrm{H}_{2} \mathrm{O}$ gas mixture (nominal gas composition) for $10 \mathrm{~h}$. If the cell is reduced under more reducing conditions (lower $\mathrm{pO}_{2}$ ) and/or at higher temperature we have observed damages to the cell due to expansion on reduction of the CGO layer and decomposition of the LSCF during reduction. The gas composition of $3.9 \% \mathrm{H}_{2}-93.2 \% \mathrm{~N}_{2}-2.9 \% \mathrm{H}_{2} \mathrm{O}$ has a theoretical $\mathrm{pO}_{2} \sim 1.6 \times 10^{-}$

${ }^{20}$ bar. The actual $\mathrm{PO}_{2}$ inside the tubular furnace is probably higher due to small leaks. Further experiments are being conducted in order to narrow down the $\mathrm{PO}_{2}$ window for the one- 
atmosphere reduction and will be reported in our future work. Afterwards, the reduced Ni/YSZ electrode was infiltrated with a nitrate solution containing stoichiometric amounts of $\mathrm{Ce}\left(\mathrm{NO}_{3}\right)_{3}$ and $\mathrm{Gd}\left(\mathrm{NO}_{3}\right)_{3}\left(4: 1\right.$ molar ratio of $\left.\mathrm{Ce}^{3+}: \mathrm{Gd}^{3+}\right)$, followed by calcination at $300{ }^{\circ} \mathrm{C}$ in air for 15 min. Note that surfactant PE-L62 (Sigma-Aldrich Corporation) with $1.4 \mathrm{wt} \%$ per weight of solution was added to improve wetting/penetration of the structure. ${ }^{12}$ The infiltration and calcination processes were repeated 9 times to get a loading of $\sim 145 \mathrm{mg}$ CGO per $1 \mathrm{~cm}^{3} \mathrm{Ni}-$ YSZ backbone (Ni/YSZ electrode + Ni/YSZ support).

SEM and XRD analysis. - The cell structures were examined using scanning electron microscopy (SEM) in a Zeiss Merlin microscope. The crystal structure of fuel electrodes was characterized by X-ray diffraction (XRD) on Bruker D8 Rigaku diffractometer using $\mathrm{Cu} \mathrm{K} \alpha$ radiation as the source. The scanning range is $20-80^{\circ}$.

Electrochemical characterization.-Electrochemical tests were conducted on the infiltrated and non-infiltrated cells using in-house constructed test rigs, as described in previous work. ${ }^{26,27}$ The active area of the cells is $4 \times 4 \mathrm{~cm}^{2}$, the edges were used for sealing. At start-up, the cells were heated $\left(1{ }^{\circ} \mathrm{C} \mathrm{min}^{-1}\right)$ to $750{ }^{\circ} \mathrm{C}$ with $5 \% \mathrm{H}_{2}-95 \% \mathrm{Ar}$ fed to the fuel electrodes and air to the oxygen electrodes with a dwelling time of $2 \mathrm{~h}$, followed by another $2 \mathrm{~h}$ with $96 \% \mathrm{H}_{2}-4 \% \mathrm{H}_{2} \mathrm{O}$ to the fuel electrodes. To evaluate the performance of the infiltrated and non-infiltrated cells, electrochemical impedance spectroscopy (EIS) measurements were performed at different temperatures, gas compositions and current loads. A Solartron 1255 frequency response analyzer in combination with a measurement resistor was used for recording the EIS, at frequencies from 0.0968 to $96850 \mathrm{~Hz}$ with 12 points per frequency decade and a perturbation amplitude of $3.75 \mathrm{~mA} \mathrm{~cm}^{-2}$. The durability of cells was evaluated at $750{ }^{\circ} \mathrm{C}$ both for steam 
electrolysis and reversible fuel cell/electrolysis operation.

\section{Results and Discussion}

Microstructure of the cells.-Figs. $2 \mathrm{a}$ and 2b,c show photographs and cross-sectional SEM images of the cell after being treated in the $\mathrm{H}_{2}-\mathrm{N}_{2}-\mathrm{H}_{2} \mathrm{O}$ gas mixture for $10 \mathrm{~h}$ at $750{ }^{\circ} \mathrm{C}$. The color of the fuel electrode has changed from green to gray, indicating the reduction of $\mathrm{NiO}$ to Ni. This reduction provides the interconnected pores needed for infiltration. Meanwhile, no obvious delamination, cracks, or other damages are observed in the LSCF/CGO oxygen electrode, the CGO barrier layer or the YSZ electrolyte. Fig. 2d shows the microstructure of the pre-reduced Ni/YSZ fuel electrode, in which a porous structure composed of clear grains is observed. Figs. $2 \mathrm{e}$ and $2 \mathrm{f}$ show that after infiltration the nanostructured CGO coatings are well deposited on the inner surfaces of the $\mathrm{Ni} / \mathrm{YSZ}$ electrode, not only on the surface of $\mathrm{Ni}$ and YSZ grains but also at the triple-phase boundaries (TPBs) where Ni, YSZ, and gas are in contact (Ni-YSZ-gas). The reduction of $\mathrm{NiO}$ to $\mathrm{Ni}$ and deposition of CGO coatings are further confirmed by the XRD patterns shown in Fig. 3.

Performance at open circuit voltage (OCV) conditions.- - To evaluate the effect of "oneatmosphere-reduction" and CGO infiltration on cell performance, EIS measurements were performed on the infiltrated cell and the "as-prepared" non-infiltrated sister-cell at $700{ }^{\circ} \mathrm{C}$ under OCV condition with different gas feeds. The intercept with the real axis at high frequency in the Nyquist plots (Figs. $4 \mathrm{a}$ and $4 \mathrm{~b})$ represents the ohmic resistance $\left(\mathrm{R}_{\mathrm{ohm}}\right)$, and the difference between the high and low frequency intercepts represents the total polarization resistance $\left(R_{p}\right)$. 
The determined values of $\mathrm{R}_{\mathrm{ohm}}$ and $\mathrm{R}_{\mathrm{p}}$ are summarized in Table 1 . To clearly compare the performance of the two cells, the EIS data recorded with $4 \% \mathrm{H}_{2} \mathrm{O}-96 \% \mathrm{H}_{2}$ fed to the fuel electrode and dry air to the oxygen electrode in Figs. $4 \mathrm{a}$ and $4 \mathrm{~b}$ have been replotted in Fig. 4c. The non-infiltrated and infiltrated cells show a similar and expected trend for $R_{o h m}$ and $R_{p}$ with the change of the gas feeds. $R_{o h m}$ is almost unaltered. $R_{p}$ decreases pronouncedly with increasing steam partial pressure from $4 \% \mathrm{H}_{2} \mathrm{O}$ to $50 \% \mathrm{H}_{2} \mathrm{O}$ at the fuel electrode, and they further decrease when the gas in the oxygen electrode compartment is changed from air to pure $\mathrm{O}_{2}$. The $\mathrm{R}_{\mathrm{ohm}}$ values are determined to be $0.260-0.265 \Omega \mathrm{cm}^{2}$ and $0.326-0.333 \Omega \mathrm{cm}^{2}$ for the non-infiltrated and the infiltrated cell, respectively. For both cells, the $\mathrm{R}_{\mathrm{ohm}}$ is much greater than the expected value of $\sim 0.06 \Omega \mathrm{cm}^{2}$, which is calculated from the thickness of the YSZ and CGO ( $8 \mu \mathrm{m}$ YSZ and $5 \mu \mathrm{m}$ thick CGO barrier) of the here investigated cells and the ionic conductivities of the two materials; $0.02 \mathrm{~S} \mathrm{~cm}^{-1}$ for $\mathrm{YSZ}$ and $0.03 \mathrm{~S} \mathrm{~cm}^{-1}$ for CGO at $700{ }^{\circ} \mathrm{C}^{28}$ This might in principle originate from poor contact in the cell-testing-setup or between the oxygen electrode and the LSM current-collector layer, but is more likely an effect of an elemental interdiffusion between CGO and YSZ which is known to reduce conductivity in both these fluorites. ${ }^{29-31} \mathrm{R}_{\mathrm{ohm}}$ of the infiltrated cell is higher than for the non-infiltrate one. Different batches of LSM inks were used for these two cells, this could be a reason for the discrepancy of $R_{\text {ohm }}$ between two cells. This discrepancy could also be due to the treatment of "oneatmosphere-reduction" on the infiltrated cell. To make this clear, further work is needed. The $\mathrm{R}_{\mathrm{p}}$ values are 0.560 and $0.483 \Omega \mathrm{cm}^{2}$ in $4 \% \mathrm{H}_{2} \mathrm{O}-96 \% \mathrm{H}_{2}$, air, 0.230 and $0.196 \Omega \mathrm{cm}^{2}$ in $50 \% \mathrm{H}_{2} \mathrm{O}-50 \% \mathrm{H}_{2}$, air, and 0.197 and $0.176 \Omega \mathrm{cm}^{2}$ in $50 \% \mathrm{H}_{2} \mathrm{O}-50 \% \mathrm{H}_{2}, \mathrm{O}_{2}$ for the non-infiltrated and the infiltrated cell, respectively. Hence, $R_{p}$ of the infiltrated cell is smaller than for the non- 
infiltrated one under all gas conditions.

In order to distinguish the different contributions to the overall $\mathrm{R}_{\mathrm{p}}$, the EIS data were analyzed by the distribution of relaxation time (DRT). ${ }^{32,33}$ The results are shown in Figs. $4 \mathrm{~d}$, $4 \mathrm{e}$, and $4 \mathrm{f}$. For both cells, five peaks $\left(\mathrm{P}_{1}, \mathrm{P}_{2}, \mathrm{P}_{3}, \mathrm{P}_{4}\right.$, and $\left.\mathrm{P}_{5}\right)$ in the frequency range of $0.1 \mathrm{~Hz}-$ $100 \mathrm{kHz}$ are identified. Each peak corresponds to an electrode process. The area enclosed by a specific peak represents the magnitude of resistance for that specific electrode process. ${ }^{34}$ As shown in Figs. $4 \mathrm{~d}$ and $4 \mathrm{e}, \mathrm{P}_{1}$ is almost independent of the gas conditions. Whereas, increasing the steam partial pressure at the fuel electrode results in a significant decrease in the peak area of $\mathrm{P}_{2}, \mathrm{P}_{4}$, and $\mathrm{P}_{5}$. Moreover, the peak position shifts to a higher frequency. The change of gas in the oxygen electrode from air to $\mathrm{O}_{2}$ leads to a change in $\mathrm{P}_{3}, \mathrm{P}_{4}$, and $\mathrm{P}_{5}$, while $\mathrm{P}_{2}$ remains almost unaltered. On the basis of these results and previously reported analyses: ${ }^{5,6,26} \mathrm{P}_{1}$ is likely related to the transport of oxygen anions through the ionic conducting networks in the electrodes. The major contribution of P1 is then expected from the fuel electrode which has a thicker and poorer conducting electrolyte network than does the oxygen electrode; $\mathrm{P}_{2}$ is associated with the steam splitting/hydrogen oxidation process at the TPBs of the fuel electrode; $\mathrm{P}_{3}$ is associated with the oxygen incorporation/evolution process at the active sites of the oxygen electrode; $\mathrm{P}_{4}$ and $\mathrm{P}_{5}$ represent the gas diffusion and the gas conversion, respectively. Fig. 4 compares the DRT plots of the two cells, showing a marked reduction in the area of $\mathrm{P}_{2}$ ascribable to the CGO fuel electrode infiltration. This is likely because the introduced CGO will show mixed electronic and oxygen ion conductivity under reducing atmosphere which provides additional active sites in the CGO modified $\mathrm{Ni} / \mathrm{YSZ}$ electrode in comparison with the $\mathrm{Ni} / Y S Z$ electrode, e.g., TPBs at the CGO, Ni and gas interface (Ni-CGO-gas), and two-phase 
boundaries (2PB) at the surface of the CGO located on Ni grains (CGO-gas). ${ }^{23,35,36}$ The smaller area of $\mathrm{P}_{3}$ for the redox cycled infiltrated cell indicates that the reduction and reoxidation at the start of testing do not harm the LSCF/CGO oxygen electrode, but it actually improves slightly. The areas of $\mathrm{P}_{4}$ and $\mathrm{P}_{5}$ are comparable for the two cells, while the corresponding frequencies of $\mathrm{P}_{4}$ and $\mathrm{P}_{5}$ shift to lower frequencies for the infiltrated cell. This frequency shift could be attributed to the slight change in the porosity of the fuel electrode after CGO infiltration.

Performance under current.-Fig. 5 compares the EIS data on non-infiltrated and infiltrated cells recorded under varying current densities from $0(\mathrm{OCV})$ to $-1.25 \mathrm{~A} \mathrm{~cm}^{-2}$ with a step size of $-0.125 \mathrm{~A} \mathrm{~cm}^{-2}$. The gas conversion is proportional to the applied current density assuming a Faraday efficiency of $100 \%$. The estimated $R_{\text {ohm }}$ of both cells varies only very little with increasing current density. For both cells the $R_{p}$ values first decrease and then increase with increasing current density, but the difference between the two cells is getting larger. At $1.25 \mathrm{~A} \mathrm{~cm}^{-2}$, the $\mathrm{R}_{\mathrm{p}}$ of the non-infiltrated cell reaches $0.294 \Omega \mathrm{cm}^{2}, \sim 41 \%$ larger than that of the infiltrated cell $\left(0.209 \Omega \mathrm{cm}^{2}\right)$. The DRT results in Figs. $5 \mathrm{c}$ and $5 \mathrm{~d}$ show that this increased difference in $\mathrm{R}_{\mathrm{p}}$ is mainly due to the different behaviors of the two cells on $\mathrm{P}_{1}$ (the transport of oxygen anions through the ionic conducting networks in the electrodes) and $\mathrm{P}_{2}$ (the steam splitting process at the TPBs in the Ni/YSZ fuel electrode). For the non-infiltrated cell, increasing the current density results in a continuous and considerable increase in $\mathrm{P}_{1}$ and $\mathrm{P}_{2}$. Whereas the infiltrated cell shows a much smaller increase in $\mathrm{P}_{2}$, and even a slight decrease in $\mathrm{P}_{1}$

These EIS data were further fitted with the equivalent circuit model shown in Fig. 6a by the complex-non-linear-least-squares (CNLS) method. ${ }^{12,37}$ Four constant phase elements (RQ) and 
a modified Gerischer element $(\mathrm{G})$ in the model correspond to the five different processes seen in the DRT. The peak frequencies observed for each peak in the DRT plots were taken as parameters for the fitting. The fitted spectra of EIS data measured at $-1.25 \mathrm{~A} \mathrm{~cm}^{-2}$ are shown in Fig. $6 b$ as examples. The corresponding relative residual plots shown in Fig. S1 indicate the good quality of fitting. The detailed fitting results are shown in Table S1. Fig. 6c compares the evolution of the fitted resistances for each process of two cells with increasing current density. The two cells show significantly different behaviors on $\mathrm{R}_{1}$ (the resistance for the transport of oxygen anions, corresponding to $\mathrm{P}_{1}$ ) and $\mathrm{R}_{2}$ (the dominant resistance term in the steam splitting process at the TPBs in the Ni/YSZ fuel electrode, corresponding to $\mathrm{P}_{2}$ ). Notably, the $\mathrm{R}_{2}$ of the non-infiltrated cell increases by a factor of $\sim 2$ when the current density is increased from 0 to $-1.25 \mathrm{~A} \mathrm{~cm}^{-2}$, while the $\mathrm{R}_{2}$ of the infiltrated cell only increases by $25 \%$. At $-1.25 \mathrm{~A} \mathrm{~cm}^{-2}$, the $\mathrm{R}_{2}$ of $0.040 \Omega \mathrm{cm}^{2}$ for the infiltrated cell is $\sim 35 \%$ that of the non-infiltrated cell $\left(0.114 \Omega \mathrm{cm}^{2}\right)$. These results suggest that the electro-catalytic activity is greatly improved on the CGO modified Ni/YSZ electrode, particularly at high current densities.

Furthermore, the $\mathrm{R}_{3}$ (the dominant resistance for the oxygen evolution reaction at the active sites in the LSCF/CGO oxygen electrode, corresponding to $\mathrm{P}_{3}$ ) of the infiltrated cell seems lower than those of the as-prepared cell, but the difference is very small and it is within the uncertainty of the fitting. Further work based on symmetrical cells has been performed to study the effect of reduction and oxidation treatments on the performance of the LSCF/CGO oxygen electrode, showing a significant decrease of $R_{p}$ after the treatment. The detailed results of symmetrical cells will be reported elsewhere. The two cells show a similar behavior on the total concentration resistance (i.e., the sum of $\mathrm{R}_{4}$ (gas diffusion, corresponding to $\mathrm{P}_{4}$ ) and $\mathrm{R}_{5}$ (gas 
conversion, corresponding to $\left.\mathrm{P}_{5}\right)$ ), which first decreased with increasing current density from 0 to $-0.75 \mathrm{~A} \mathrm{~cm}^{-2}$ (corresponding to a decrease in steam content of gas mixture from $90 \%$ to $67 \%$ ) and then increased. Based on the plug-flow model described in ref. ${ }^{38}$, starting from a $90 \% \mathrm{H}_{2} \mathrm{O}-10 \% \mathrm{H}_{2}$ mixture the concentration resistance will decrease with increasing current density as the composition approaches the $50 \% \mathrm{H}_{2} \mathrm{O}-50 \% \mathrm{H}_{2}$ mixture where the concentration resistance is minimal whereafter it increases again. The change of concentration resistance with current density in Fig. 6c is faster than theoretically calculated, and similar behavior has also been observed by Mogensen et al. ${ }^{38}$

Durability for steam electrolysis and reversible operation.-Fig.7 compares the durability of non-infiltrated and infiltrated cells for steam electrolysis, tested at $750{ }^{\circ} \mathrm{C}$ with current density maintained first at -1.25 and then $-1.00 \mathrm{~A} \mathrm{~cm}^{-2}$. Assuming a Faraday efficiency of $100 \%$, the $\mathrm{H}_{2}$ production rates for the two cells reach 8.70 and $6.96 \mathrm{ml} \mathrm{min}^{-1} \mathrm{~cm}^{-2}$ at -1.25 and $-1.00 \mathrm{~A} \mathrm{~cm}^{-2}$, respectively, corresponding to steam utilization of 42 and $33 \%$. Fig. 7 a shows the evolution of cell voltage with time. When operated at $-1.25 \mathrm{~A} \mathrm{~cm}^{-2}$, the initial voltage of the non-infiltrated cell is $1.385 \mathrm{~V}$, and it decreases to $1.377 \mathrm{~V}$ over the first $15 \mathrm{~h}$, then increases rapidly to $1.503 \mathrm{~V}$ in the following $285 \mathrm{~h}$, corresponding to a degradation rate of $0.442 \mathrm{~V} \mathrm{kh}^{-1}$ $\left(32.1 \% \mathrm{kh}^{-1}\right)$. In contrast, the initial voltage of the infiltrated cell is $1.408 \mathrm{~V}$, and it decreases continuously to $1.350 \mathrm{~V}$ over the first $300 \mathrm{~h}$, then increases to $1.372 \mathrm{~V}$ over the following 800 $\mathrm{h}$, corresponding to a degradation rate of $0.028 \mathrm{~V} \mathrm{kh}^{-1}\left(2.0 \% \mathrm{kh}^{-1}\right), \sim 14$ times smaller than the degradation rate for the non-infiltrated cell when assessed over these selected periods. Subsequently, the durability of the cells was tested at $-1.00 \mathrm{~A} \mathrm{~cm}^{-2}$. For the non-infiltrated cell, the voltage increases from $1.385 \mathrm{~V}$ to $1.464 \mathrm{~V}$ in $300 \mathrm{~h}$ (from 315 to $615 \mathrm{~h}$ ), corresponding to 
a degradation rate of $0.263 \mathrm{~V} \mathrm{kh}^{-1}\left(19.0 \% \mathrm{kh}^{-1}\right)$. Whereas the infiltrated cell has a much lower voltage of $1.280 \mathrm{~V}$ initially, and the voltage increases only $0.003 \mathrm{~V}$ over the next $300 \mathrm{~h}$ (from 1130 to $1430 \mathrm{~h})$, corresponding to a degradation rate of $0.010 \mathrm{~V} \mathrm{kh}^{-1}\left(0.8 \% \mathrm{kh}^{-1}\right)$, a factor of 25 smaller than that of the non-infiltrated cell. This cell can effectively be operated with very small degradation $\left(0.8 \% \mathrm{kh}^{-1}\right)$ at thermo-neutral voltage yielding a current density of $-1.00 \mathrm{~A}$ $\mathrm{cm}^{-2}$ at $750{ }^{\circ} \mathrm{C}$. Clearly, the durability of the infiltrated cell is far superior to the non-infiltrated cell, demonstrating the feasibility of enhancing cell durability via the applied approach; where the full cell is placed in reducing environment and after the treatment the $\mathrm{Ni} / \mathrm{YSZ}$ electrode is infiltrated. The reduction step could conveniently be carried out as the last step in the cell manufacturing process; during cooling after firing the oxygen electrode, the atmosphere is changed to the specified mixture of $\mathrm{H}_{2}-\mathrm{N}_{2}-\mathrm{H}_{2} \mathrm{O}$.

The durability of the infiltrated cell is further compared with those of previously reported cells tested under high current densities. Note that not only the current density but also the steam conversion and operating temperature will have significant effect on cell durability. A degradation rate of $0.040 \mathrm{~V} \mathrm{kh}^{-1}\left(3.8 \% \mathrm{kh}^{-1}, \sim 4\right.$ times that of the infiltrated cell) was reported for $9000 \mathrm{~h}$ operation under $-1.00 \mathrm{~A} \mathrm{~cm}^{-2}$ and a slightly higher steam conversion of $36 \%$ but at a higher temperature of $\sim 775{ }^{\circ} \mathrm{C}$ on a Ni/YSZ fuel-electrode supported cell with a thin YSZ electrolyte, a CGO barrier, and a screen printed $\mathrm{La}_{0.58} \mathrm{Sr}_{0.4} \mathrm{Co}_{0.2} \mathrm{Fe}_{0.8} \mathrm{O}_{3-\delta}$ oxygen electrode. ${ }^{11} \mathrm{~A}$ degradation rate of $\sim 0.007 \mathrm{~V} \mathrm{kh}^{-1}\left(<0.6 \% \mathrm{kh}^{-1}\right.$, i.e., $70 \%$ that of the infiltrated cell) was reported for a scandia/ceria doped zirconia electrolyte (6Sc1CeSZ)-supported cell with CGO diffusion-barrier/adhesion layers, an LSCF oxygen electrode, and a Ni/CGO fuel electrode under a higher steam conversion of $51 \%$ but at a lower current density of $-0.90 \mathrm{~A} \mathrm{~cm}^{-2}$ and a 
much higher temperature of $847^{\circ} \mathrm{C} .{ }^{39}$ Furthermore, a degradation rate as low as $0.3-0.4 \% \mathrm{kh}^{-}$ ${ }^{1}\left(\sim 50 \%\right.$ that of the infiltrated cell) was reported under $-1.00 \mathrm{~A} \mathrm{~cm}^{-2}$ at a higher temperature of $800{ }^{\circ} \mathrm{C}$ but at a higher steam conversion of $56 \%$ on a fuel-electrode-supported cell with an optimized Ni/YSZ fuel electrode and a $\mathrm{La}_{0.6} \mathrm{Sr}_{0.4} \mathrm{CoO}_{3-\delta}$ (LSC)/CGO oxygen electrode developed previously in our laboratory. ${ }^{6}$ This comparison illustrates the challenge in comparing data obtained under different experimental conditions. To elucidate effects of test conditions on fuel electrode degradation on different electrodes it would likely be valuable to compare durability at a fixed electrode polarization. However, this is not trivial to extract accurately. Another relevant way to compare would be to consider changes in performance at comparable power inputs. It is clear that the infiltration treatment discussed here benefits cell durability and technologically interesting performance levels are demonstrated $\left(0.8 \% \mathrm{kh}^{-1}\right.$ at $-1.00 \mathrm{~A} \mathrm{~cm}^{-2}$, $\sim 1.28 \mathrm{~V}$ ). In terms of benchmarking against previously reported cell-durabilities at high production capacity the performance here is inferior to the reports in Ref. 6 , where $0.4 \% \mathrm{kh}^{-1}$ at $-1.00 \mathrm{~A} \mathrm{~cm}^{-2}$ was recorded at slightly lower voltage $(\sim 1.22 \mathrm{~V})$ and higher conversion. ${ }^{6}$

Figs. $7 \mathrm{~b}-7 \mathrm{e}$ shows the Nyquist plots of the EIS data recorded under current during the durability tests. After $300 \mathrm{~h}$ at $-1.25 \mathrm{~A} \mathrm{~cm}^{-2}, \mathrm{R}_{\mathrm{ohm}}$ and $\mathrm{R}_{\mathrm{p}}$ of the non-infiltrated cell increase $0.007 \Omega \mathrm{cm}^{2}$ and $0.079 \Omega \mathrm{cm}^{2}$, respectively (Fig. $7 \mathrm{~b}$ ). The increase in $\mathrm{R}_{\mathrm{p}}$ contributes $\sim 92 \%$ of the total resistance increase, showing that the cell degradation processes occur mainly on the electrodes. The significant increase in $\mathrm{P}_{2}$ in the corresponding DRT plots for the non-infiltrated cell reveals that the major degradation is from the Ni/YSZ fuel electrode (Fig. 8a). Supporting this is also the observation of an additional "negative loop" appearing in the low-frequency 
range in the Nyquist plot after $300 \mathrm{~h}$ operation (Fig. 7b), which has been shown to originate from the reduction of YSZ in the Ni/YSZ electrode. ${ }^{4,40}$ For the infiltrated cell, both $\mathrm{R}_{\mathrm{ohm}}$ and $\mathrm{R}_{\mathrm{p}}$ decreased in the first $300 \mathrm{~h}$ (Fig. 7c). Furthermore, a decrease in $\mathrm{P}_{2}$ is observed in the corresponding DRT plots (Fig. 8b), which is attributed to an activation of the CGO modified $\mathrm{Ni} / Y S Z$ fuel electrode. In the next $800 \mathrm{~h}, \mathrm{R}_{\mathrm{ohm}}$ is almost stable and the $\mathrm{R}_{\mathrm{p}}$ only increases 0.027 $\Omega \mathrm{cm}^{2}$. The corresponding increase in $\mathrm{P}_{2}$ (Fig. $8 \mathrm{~b}$ ) is much smaller than that for the noninfiltrated cell (Fig. 8a). For the subsequent $300 \mathrm{~h}$ operation at $-1.00 \mathrm{~A} \mathrm{~cm}^{-2}$, the increase of $\mathrm{R}_{\mathrm{ohm}}$ and $\mathrm{R}_{\mathrm{p}}$ on the non-infiltrated cell are $0.030 \Omega \mathrm{cm}^{2}$ and $0.044 \Omega \mathrm{cm}^{2}$, respectively (Fig. $7 \mathrm{~d}$ ). Whereas, the increase of $R_{o h m}$ and $R_{p}$ on the infiltrated cell are only $0.001 \Omega \mathrm{cm}^{2}$ and $0.005 \Omega$ $\mathrm{cm}^{2}$, respectively (Fig. 7e). Similar to the observation at $-1.25 \mathrm{~A} \mathrm{~cm}^{-2}$, the increase in $\mathrm{P}_{2}$ is also significantly reduced for the infiltrated cell when operated at $-1.00 \mathrm{~A} \mathrm{~cm}^{-2}$ (Figs. $8 \mathrm{c}$ and $8 \mathrm{~d}$ ). These EIS results are consistent with the cell voltage evolution results plotted in Fig. 7a, and they demonstrate that the applied approach of "one-atmosphere-reduction" and CGO infiltration can effectively improve the durability of Ni/YSZ fuel electrode when operated at or above $-1 \mathrm{~A} \mathrm{~cm}^{-2}$. The reasons for the improved durability on the CGO modified Ni/YSZ electrode here should be similar to the findings in our previous work (where the CGO was introduced into the Ni/YSZ electrode after the "two-atmosphere-reduction"), i.e., mitigating microstructural deterioration including Ni migration and disconnection between $\mathrm{Ni}$ and YSZ at the TPBs seen on nonmodified Ni/YSZ electrodes. ${ }^{12,23}$

After steam electrolysis, the infiltrated cell was further investigated for reversible operation under a current density of first $+/-0.50$ and then $+/-1.00 \mathrm{~A} \mathrm{~cm}^{-2}$ at $750{ }^{\circ} \mathrm{C}$ (Fig. 9a). Under each current, the cell was operated for $120 \mathrm{~h}$ in fuel cell mode and $120 \mathrm{~h}$ in electrolysis mode 
before shifted to cyclic operation with time periods of $3 \mathrm{~h}$ in fuel cell mode and $20 \mathrm{~h}$ in electrolysis mode. The $\mathrm{H}_{2}$ and steam utilization were adjusted to be $52 \%$ during reversible operation. When operated at $+/-0.50 \mathrm{~A} \mathrm{~cm}^{-2}$, no obvious signs of degradation could be observed on the infiltrated cell. For comparison, a new "as prepared" non-infiltrated cell was tested under the same cycling conditions. The new non-infiltrated cell was used because the previous one has degraded a lot after the steam electrolysis test and its performance is too poor for further investigation. Fig. 9b illustrates the behavior; $0.016 \mathrm{~V}$ increase in cell voltage after $120 \mathrm{~h}$ at $-0.50 \mathrm{~A} \mathrm{~cm}^{-2}$, corresponding to a degradation rate of $\sim 0.133 \mathrm{~V} \mathrm{kh}^{-1} ; 0.148 \mathrm{~V}$ increase in cell voltage after 26 cycles at $+/-0.50 \mathrm{~A} \mathrm{~cm}^{-2}$, corresponding to a degradation rate of $\sim 0.006$ $\mathrm{V}$ per cycle). Note that a degradation rate of $\sim 0.003 \mathrm{~V}$ per cycle was reported under identical conditions on the previously mentioned fuel-electrode-supported cell with the optimized $\mathrm{Ni} / Y S Z$ fuel electrode and the LSC/CGO oxygen electrode. ${ }^{41}$ In addition, a degradation rate of $\sim 0.001 \mathrm{~V}$ per cycle was reported under same conditions but at $50{ }^{\circ} \mathrm{C}$ lower testing temperature $\left(700{ }^{\circ} \mathrm{C}\right)$ on a fuel-electrode-supported cell with the optimized $\mathrm{Ni} / \mathrm{YSZ}$ fuel electrode but a LSC infiltrated CGO oxygen electrode developed in our laboratory. ${ }^{41}$ For reversible operation under $+/-1.00 \mathrm{~A} \mathrm{~cm}^{-2}$, the infiltrated cell shows $0.009 \mathrm{~V}$ increase in cell voltage after $120 \mathrm{~h}$ at $-1.00 \mathrm{~A} \mathrm{~cm}^{-2}$, corresponding to a degradation rate of $\sim 0.075 \mathrm{~V} \mathrm{kh}^{-1} ; 0.029 \mathrm{~V}$ increase in cell voltage after 11 cycles at $+/-1.00 \mathrm{~A} \mathrm{~cm}^{-2}$, corresponding to a degradation rate of $\sim 0.003 \mathrm{~V}$ per cycle. These degradation rates measured at $+/-1.00 \mathrm{~A} \mathrm{~cm}^{-2}$ are $\sim 50 \%$ less than those of the non-infiltrated cell at lower current of $+/-0.50 \mathrm{~A} \mathrm{~cm}^{-2}$. Accordingly, the infiltrated cell showed significantly improved durability compared with the non-infiltrated cell during reversible operation. 
It has here been demonstrated that tailoring of the Ni/YSZ electrode by infiltration can be done at single cell level even after reducing the full cell. This is practical from a manufacturing point of view compared to previously applied "two-atmosphere" treatments and has some distinct advantages over a post-stack assembly infiltration ${ }^{24}$ as was discussed in ref ${ }^{42}$. First, it allows more careful quality and process control at single cell level when all steps in the cell manufacturing have been completed. Also, the cells are in fact more robust for strain loading,

${ }^{42}$ when in reduced state than when in oxidized state, which can be an advantage in handling and during stacking.

\section{Conclusions}

In summary, we demonstrated an up-scalable, effective route for infiltrating CGO electrocatalysts into the Ni/YSZ electrode after exposing the full cell to a "one-atmospherereduction". When operated for steam electrolysis at $750{ }^{\circ} \mathrm{C}$, the observed cell voltage degradation rates of the infiltrated cell are $0.028 \mathrm{~V} \mathrm{kh}^{-1}\left(2.0 \% \mathrm{kh}^{-1}\right)$ at $-1.25 \mathrm{~A} \mathrm{~cm}^{-2}$ and 0.010 $\mathrm{V} \mathrm{kh}^{-1}\left(0.8 \% \mathrm{kh}^{-1}\right)$ at $-1.00 \mathrm{~A} \mathrm{~cm}^{-2}, \sim 14$ times and $\sim 25$ times smaller than the degradation rates for the non-infiltrated cell, respectively. For reversible operation at $+/-0.50 \mathrm{~A} \mathrm{~cm}^{-2}$, no obvious signs of degradation could be observed on the infiltrated cell, showing significantly improved durability compared with the non-infiltrated cell. The results of EIS data recorded under current load substantiate the finding that the CGO infiltration not only clearly improves the electro-catalytic activity of the Ni/YSZ electrode at high current densities but also strongly enhances the electrode durability. The EIS results also demonstrate a small improvement of the performance of the LSCF/CGO oxygen electrode after the redox cycle introduced via the "one- 
atmosphere-reduction" and the subsequent reoxidation at the start of testing.

\section{Acknowledgments}

The authors gratefully acknowledge part funding from Danish TSO - Energinet.dk through the project "Towards Solid Oxide Electrolysis Plants in 2020" (ForskEL 2015-1-12276), EUDP through the project "Efficient Power2Gas Combining SOEC and Biomass Gasification" (EUDP no. 64017-0011), European Union's Horizon 2020 through the project "BALANCE Increasing penetration of renewable power, alternative fuels and grid flexibility by cross-vector electrochemical processes" (No. 731224), and Innovation Fund Denmark through project "Synfuel" (4106-00006B). X. F. Tong acknowledges financial support from the China Scholarship Council (CSC). The authors are also grateful towards H. Henriksen for help with experimental work on cell testing.

\section{ORCID}

Xiaofeng Tong: 0000-0003-2227-7441

Peter Vang Hendriksen: 0000-0002-4748-532X

Anne Hauch: 0000-0001-8198-9399

Xiufu Sun: 0000-0001-8503-9745

Ming Chen: 0000-0001-6387-3739

\section{References}


1. T. M. Gür, Energy Environ. Sci., 11, 2696 (2018).

2. R. Adib, H. Murdock, F. Appavou, A. Brown, B. Epp, A. Leidreiter, C. Lins, H.

Murdock, E. Musolino and K. Petrichenko, Paris: REN21 Secretariat (2015),

https://www.ren21.net/wp-content/uploads/2019/05/GSR2015_Full-Report_English.pdf.

3. J. T. S. Irvine, D. Neagu, M. C. Verbraeken, C. Chatzichristodoulou, C. Graves and M. B. Mogensen, Nat. Energy, 1, 15014 (2016).

4. M. Chen, Y. L. Liu, J. J. Bentzen, W. Zhang, X. Sun, A. Hauch, Y. Tao, J. R. Bowen and P. V. Hendriksen, J. Electrochem. Soc., 160, F883 (2013).

5. M. Chen, X. Sun, C. Chatzichristodoulou, S. Koch, P. V. Hendriksen and M. B. Mogensen, ECS Trans., 78, 3077 (2017).

6. A. Hauch, K. Brodersen, M. Chen and M. B. Mogensen, Solid State Ionics, 293, 27 (2016).

7. D. The, S. Grieshammer, M. Schroeder, M. Martin, M. Al Daroukh, F. Tietz, J. Schefold and A. Brisse, J Power Sources, 275, 901 (2015).

8. A. Hauch, M. Marchese, A. Lanzini and C. Graves, J Power Sources, 377, 110 (2018).

9. P. Hjalmarsson, X. Sun, Y.-L. Liu and M. Chen, J Power Sources, 262, 316 (2014).

10. A. Nechache, B. A. Boukamp, M. Cassir and A. Ringuedé, J Solid State Electr, 23, 109 (2018).

11. F. Tietz, D. Sebold, A. Brisse and J. Schefold, J Power Sources, 223, 129 (2013).

12. S. Ovtar, X. Tong, J. J. Bentzen, K. T. S. Thyden, S. B. Simonsen and M. Chen, Nanoscale, 11, 4394 (2019).

13. A. Hauch, S. r. H. j. Jensen, J. r. B. Bilde-Sorensen and M. Mogensen, J. Electrochem. 
Soc., 154, A619 (2007).

14. S. D. Ebbesen, C. Graves, A. Hauch, S. r. H. Jensen and M. Mogensen, J. Electrochem. Soc., 157, B1419 (2010).

15. K. Lillmaa, M. Maide, R. Kanarbik, G. Nurk and E. Lust, J. Electrochem. Soc., 163, F3190 (2016).

16. X. Yang and J. T. S. Irvine, J Mater Chem, 18, 2349 (2008).

17. C. Jin, C. H. Yang, F. Zhao, D. Cui and F. L. Chen, Int. J. Hydrogen Energy, 36, 3340 (2011).

18. S. Li, Y. Li, Y. Gan, K. Xie and G. Meng, J Power Sources, 218, 244 (2012).

19. G. Tsekouras, D. Neagu and J. T. S. Irvine, Energy Environ. Sci., 6, 256 (2013).

20. J. H. Myung, D. Neagu, D. N. Miller and J. T. Irvine, Nature, 537, 528 (2016).

21. Y. Wang, T. Liu, M. Li, C. Xia, B. Zhou and F. Chen, J. Mater. Chem. A, 4, 14163 (2016).

22. Y. H. Li, P. Li, B. B. Hu and C. R. Xia, J. Mater. Chem. A, 4, 9236 (2016).

23. X. Tong, S. Ovtar, K. Brodersen, P. V. Hendriksen and M. Chen, ACS Appl Mater Interfaces, 11, 25996 (2019).

24. R. Kiebach, P. Zielke, J. V. T. Høgh, K. Thydén, H. J. Wang, R. Barford and P. V. Hendriksen, Fuel Cells, 16, 80 (2016).

25. A. Hagen, M. Menon, R. Barfod, P. V. Hendriksen, S. Ramousse and P. H. Larsen, Fuel Cells, 6, $146(2006)$.

26. S. H. Jensen, A. Hauch, P. V. Hendriksen and M. Mogensen, J. Electrochem. Soc., 156, B757 (2009).

27. S. D. Ebbesen, C. Graves, A. Hauch, S. H. Jensen and M. Mogensen, J. Electrochem. 
Soc., 157, B1419 (2010).

28. A. Tsoga, Solid State Ionics, 135, 403 (2000).

29. A. Tsoga, A. Gupta, A. Naoumidis and P. Nikolopoulos, Acta Mater., 48, 4709 (2000).

30. A. Tsoga, A. Naoumidis, A. Gupta and D. Stöver, Mater. Sci. Forum, 308-311, 794 (1999).

31. H. Xu, K. Cheng, M. Chen, L. Zhang, K. Brodersen and Y. Du, J Power Sources, 441, $227152(2019)$

32. A. Leonide, V. Sonn, A. Weber and E. Ivers-Tiffée, J. Electrochem. Soc., 155, B36 (2008).

33. B. A. Boukamp and A. Rolle, Solid State Ionics, 314, 103 (2018).

34. X. Zhang, L. Liu, Z. Zhao, B. Tu, D. Ou, D. Cui, X. Wei, X. Chen and M. Cheng, Nano Lett., 15, 1703 (2015).

35. W. C. Chueh, C. Falter, M. Abbott, D. Scipio, P. Furler, S. M. Haile and A. Steinfeld, Science, 330, 1797 (2010).

36. V. Papaefthimiou, D. K. Niakolas, F. Paloukis, D. Teschner, A. Knop-Gericke, M. Haevecker and S. Zafeiratos, J. Catal., 352, 305 (2017).

37. P. Hjalmarsson, X. Sun, Y.-L. Liu and M. Chen, J Power Sources, 223, 349 (2013).

38. M. B. Mogensen, S. D. Ebbesen, S. H. Jensen, X. Sun, A. Hauch and M. Chen, ECS Trans., 78, 2133 (2017).

39. J. Schefold, A. Brisse and H. Poepke, Electrochim. Acta, 179, 161 (2015).

40. K. V. Hansen, M. Chen, T. Jacobsen, K. Thydén, S. B. Simonsen, S. Koch and M. B. Mogensen, J. Electrochem. Soc., 163, F1217 (2016). 
41. X. Sun, B. R. Sudireddy, X. Tong, M. Chen, K. Brodersen and A. Hauch, ECS Trans., 91, 2631 (2019).

42. P. V. Hendriksen, X. F. Tong, M. Chen, S. Ovtar, H. L. Frandsen, P. Khajavi and K. R., in $13^{\text {th }}$ European SOFC \& SOE Forum, A1506, Lucerne/Switzerland (2018). 
Table 1. $\mathrm{R}_{\mathrm{ohm}}$ and $\mathrm{R}_{\mathrm{p}}$ of the non-infiltrated and infiltrated cells under different gas conditions at $700{ }^{\circ} \mathrm{C}$. The resistances were determined from Nyquist plots in Fig. 4, and the units for these values are $\Omega \mathrm{cm}^{2}$.

\begin{tabular}{llclc}
\hline \multirow{2}{*}{ Gas conditions } & \multicolumn{2}{c}{ Non-infiltrated } & \multicolumn{2}{c}{ Infiltrated } \\
\cline { 2 - 5 } & $\mathrm{R}_{\mathrm{ohm}}$ & $\mathrm{R}_{\mathrm{p}}$ & $\mathrm{R}_{\mathrm{ohm}}$ & $\mathrm{R}_{\mathrm{p}}$ \\
\hline $4 \% \mathrm{H}_{2} \mathrm{O}-96 \% \mathrm{H}_{2}$, air & 0.262 & 0.560 & 0.331 & 0.483 \\
\hline $50 \% \mathrm{H}_{2} \mathrm{O}-50 \% \mathrm{H}_{2}$, air & 0.265 & 0.230 & 0.333 & 0.196 \\
\hline $50 \% \mathrm{H}_{2} \mathrm{O}-50 \% \mathrm{H}_{2}, \mathrm{O}_{2}$ & 0.260 & 0.197 & 0.326 & 0.176 \\
\hline
\end{tabular}




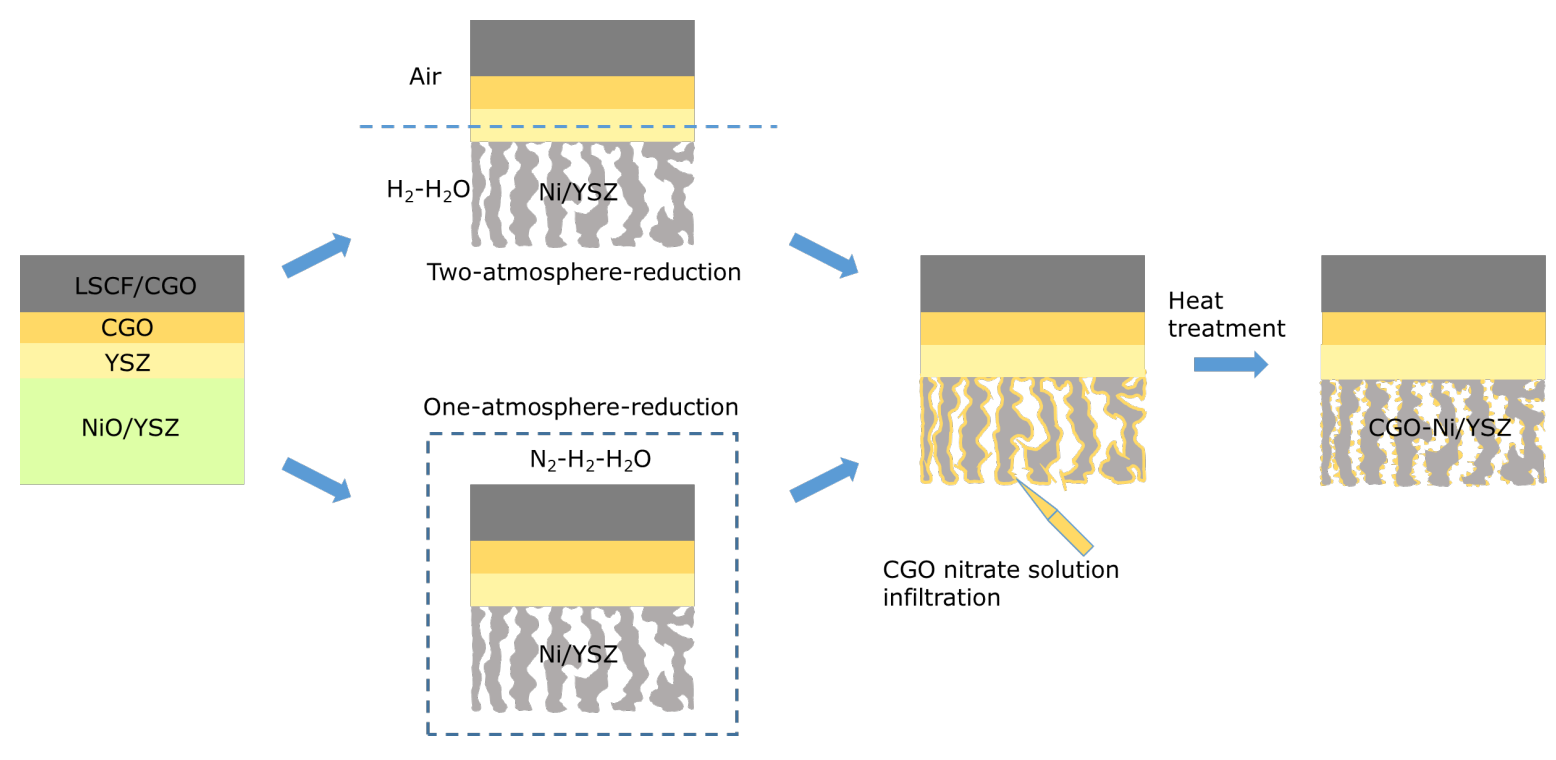

Figure 1. Schematic illustration of different cell preparation routes enabling the reduction of $\mathrm{NiO}$ to Ni prior to modifying the Ni/YSZ electrode with CGO electrocatalysts. 
a $\mathrm{Ni} /$ YSZ fuel LSCF/CGO oxygen electrode electrode, LSM contact
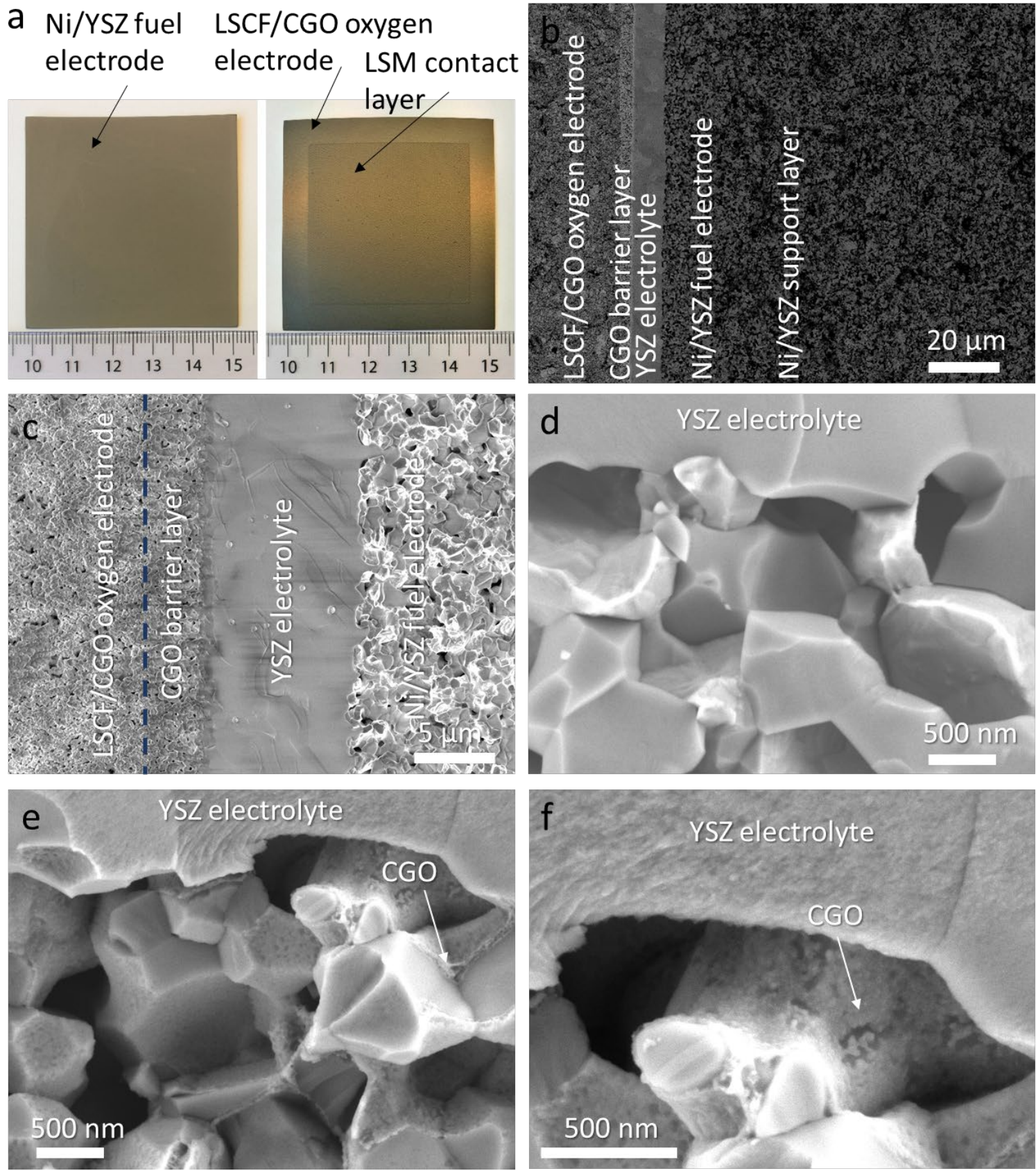

Figure 2. (a) Photographs and $(b, c)$ cross-sectional SEM images of fuel-electrode-supported cell after "one-atmosphere-reduction". Cross-sectional SEM images of (d) Ni/YSZ fuel electrode and (e,f) Ni/YSZ fuel electrode infiltrated with CGO electrocatalysts. 


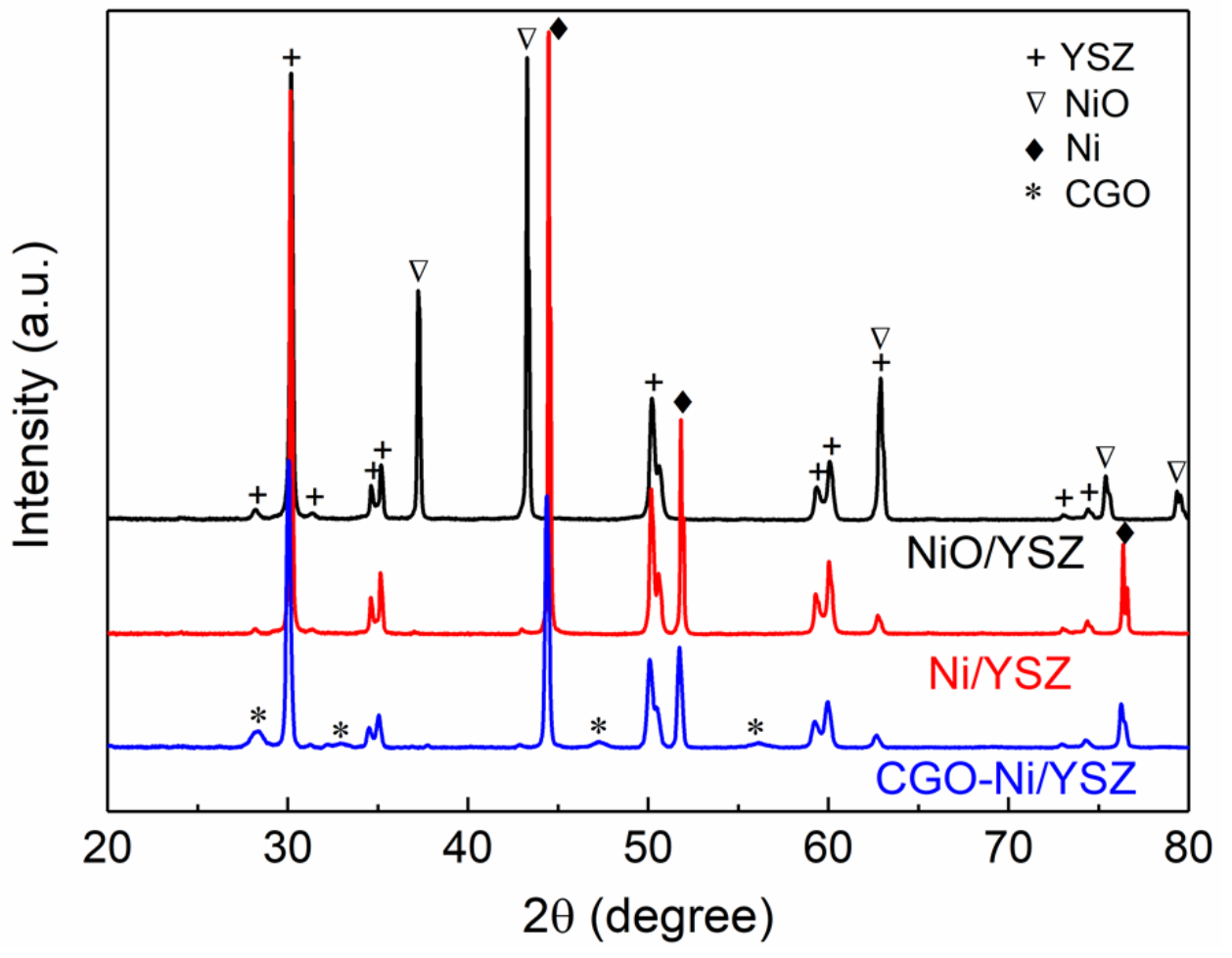

Figure 3. XRD patterns of (a) $\mathrm{NiO} / \mathrm{YSZ}$ electrode, (b) Ni/YSZ electrode reduced in $\mathrm{N}_{2}-\mathrm{H}_{2}-$ $\mathrm{H}_{2} \mathrm{O}$ at $750^{\circ} \mathrm{C}$ for $10 \mathrm{~h}$, and (c) Ni/YSZ electrode infiltrated with CGO electrocatalysts. 

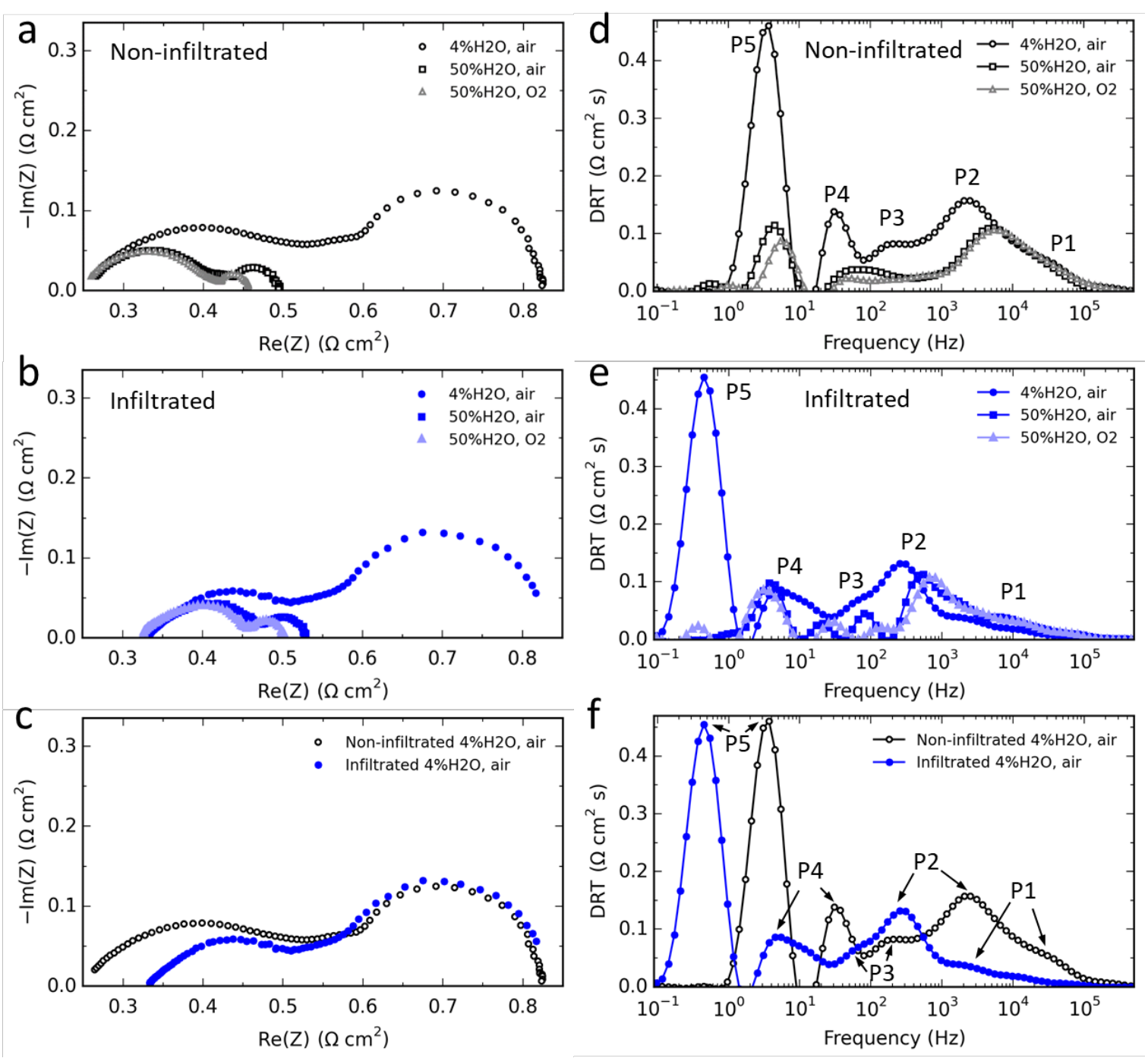

Figure 4. EIS data recorded at $700{ }^{\circ} \mathrm{C}$ and open circuit voltage with varying gas feeds to the electrodes. Nyquist plots and DRT plots $(a, d)$ of the non-infiltrated cell, and $(b, e)$ infiltrated cell. Comparison of the (c) Nyquist and (d) DRT plots of the non-infiltrated cell and the infiltrated cell. 

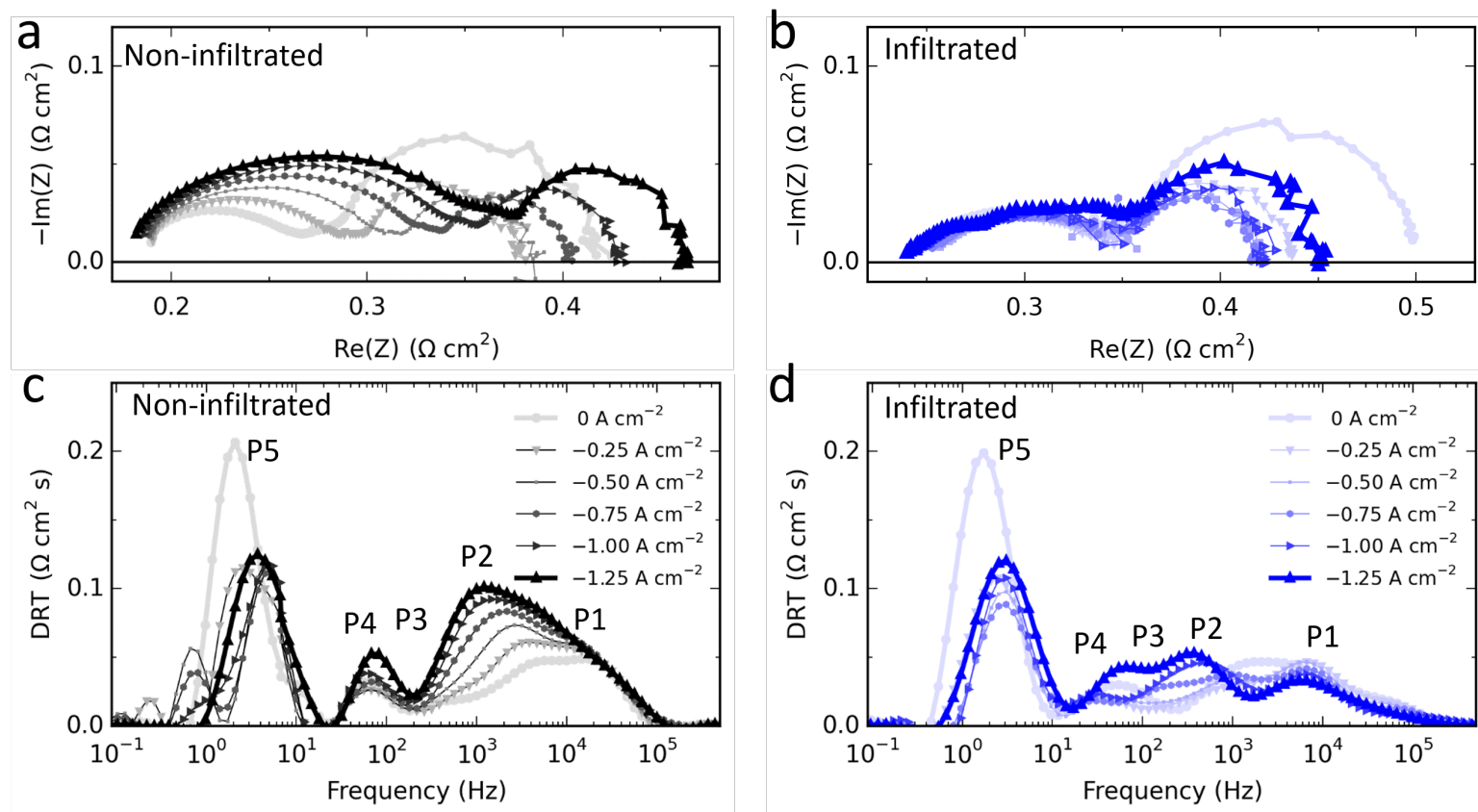

Figure 5. Nyquist plots and DRT plots of the EIS data recorded on $(\mathrm{a}, \mathrm{c})$ non-infiltrated cell and $(\mathrm{d}, \mathrm{e})$ infiltrated cell under varying applied current densities at $750{ }^{\circ} \mathrm{C}$ with $22.21 \mathrm{~h}^{-1}$ of $90 \% \mathrm{H}_{2} \mathrm{O}-10 \% \mathrm{H}_{2}$ fed to the fuel electrode and $50 \mathrm{l} \mathrm{h}^{-1}$ pure $\mathrm{O}_{2}$ to the oxygen electrode. Note that the small peaks observed at frequencies below $1 \mathrm{~Hz}$ in Fig. $5 \mathrm{c}$ is likely due to the increased noise of impedance data at low frequency shown in Fig. 5a. 

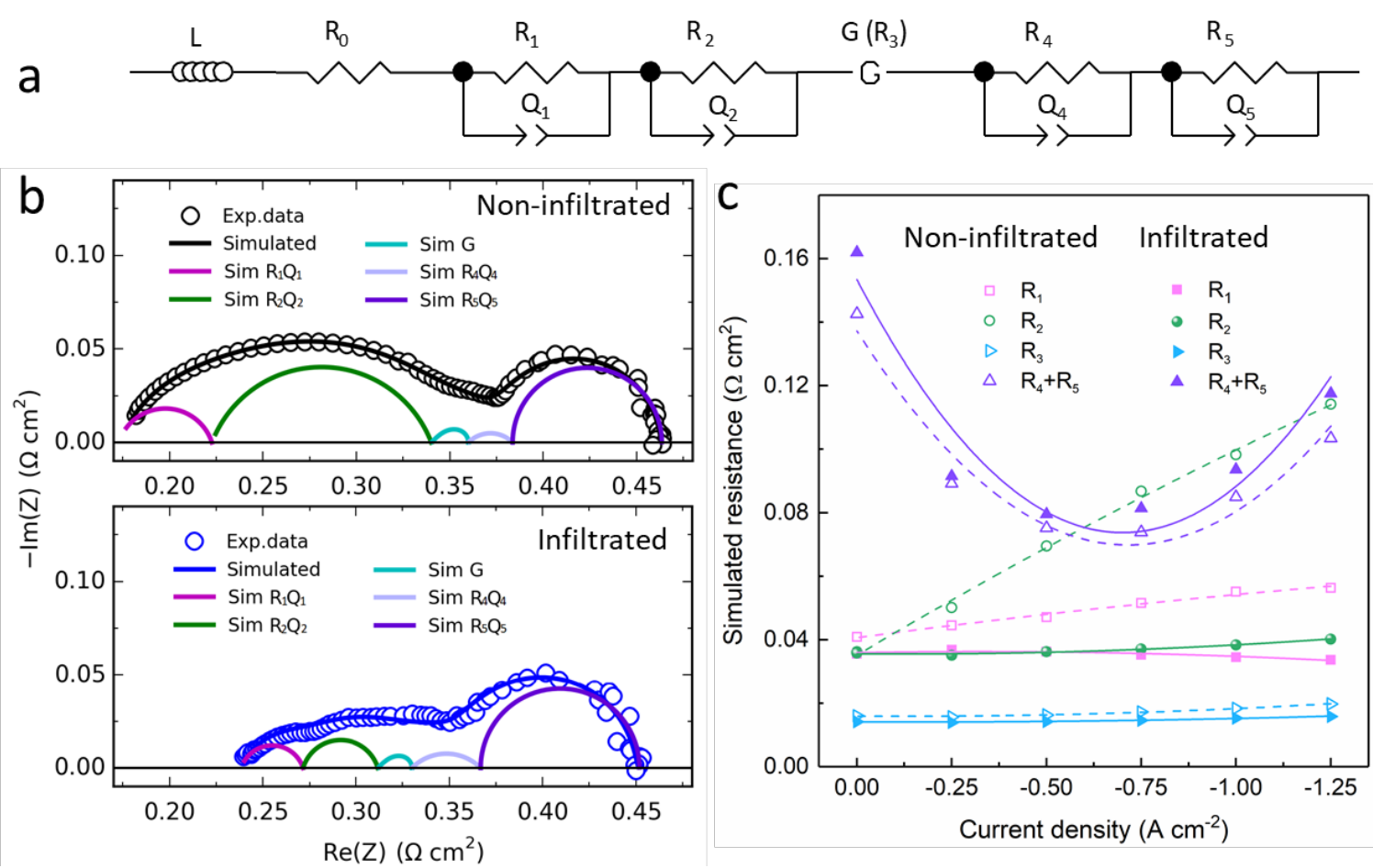

Figure 6. (a) Electrical equivalent circuit model for CNLS fits. (b) CNLS fits of EIS data recorded under $-1.25 \mathrm{~A} \mathrm{~cm}^{-2}$ for the non-infiltrated and the infiltrated cells. (c) Resistances from the fitting results. 

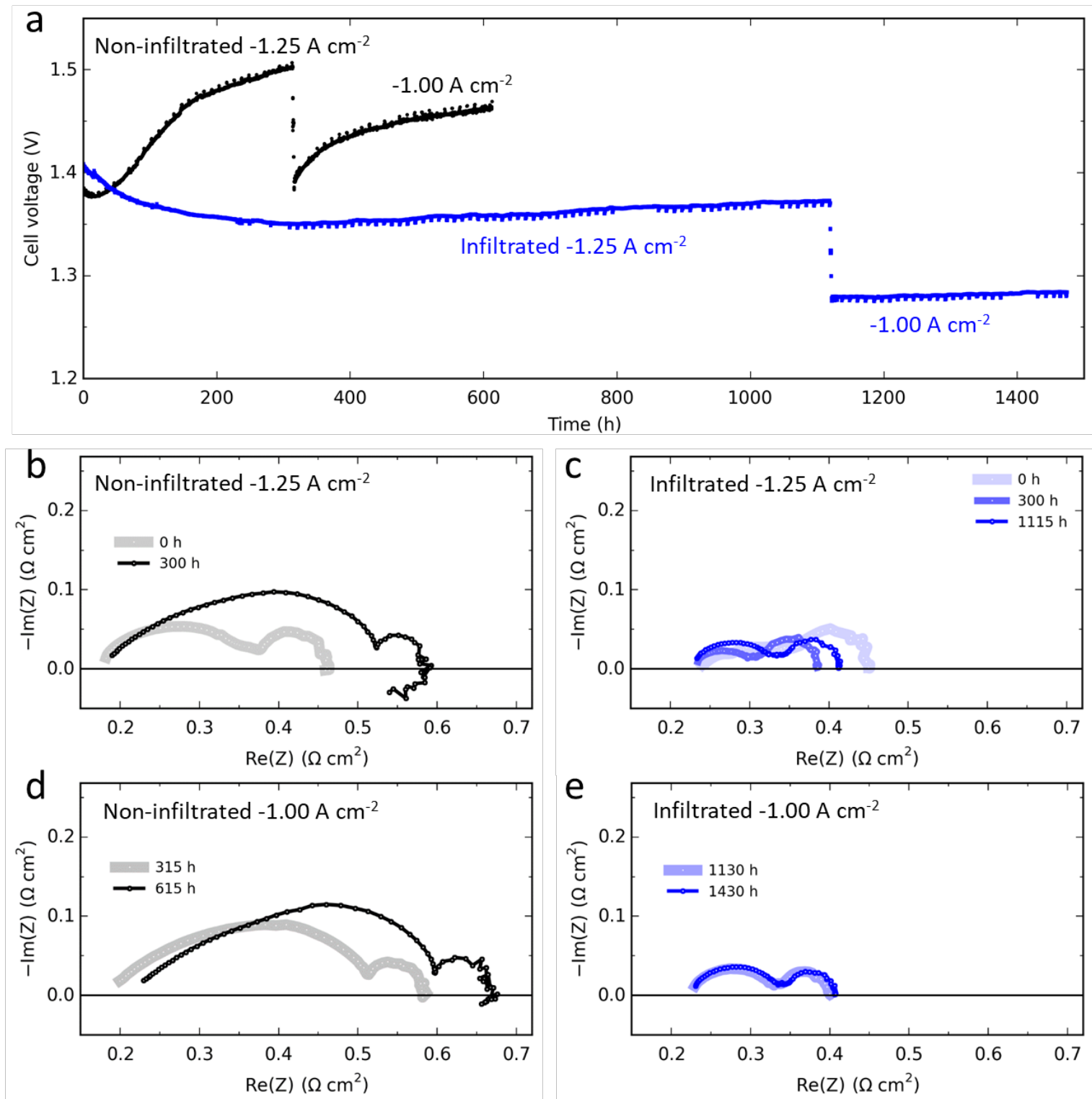

Figure 7. Comparison of the cell durability during steam electrolysis at $750{ }^{\circ} \mathrm{C}$ with $22.21 \mathrm{~h}^{-1}$ of $90 \% \mathrm{H}_{2} \mathrm{O}-10 \% \mathrm{H}_{2}$ to the fuel electrode and $501 \mathrm{~h}^{-1}$ pure $\mathrm{O}_{2}$ to the oxygen electrode. (a) Evolution of cell voltage as a function of time. Nyquist plots of EIS data recorded under current during the durability test period. (b) $-1.25 \mathrm{~A} \mathrm{~cm}^{-2}$ on the non-infiltrated cell, (c) $-1.25 \mathrm{~A}$ $\mathrm{cm}^{-2}$ on the infiltrated cell, (d) $-1.00 \mathrm{~A} \mathrm{~cm}^{-2}$ on the non-infiltrated cell, and (e) $-1.00 \mathrm{~A} \mathrm{~cm}^{-2}$ on the infiltrated cell. 

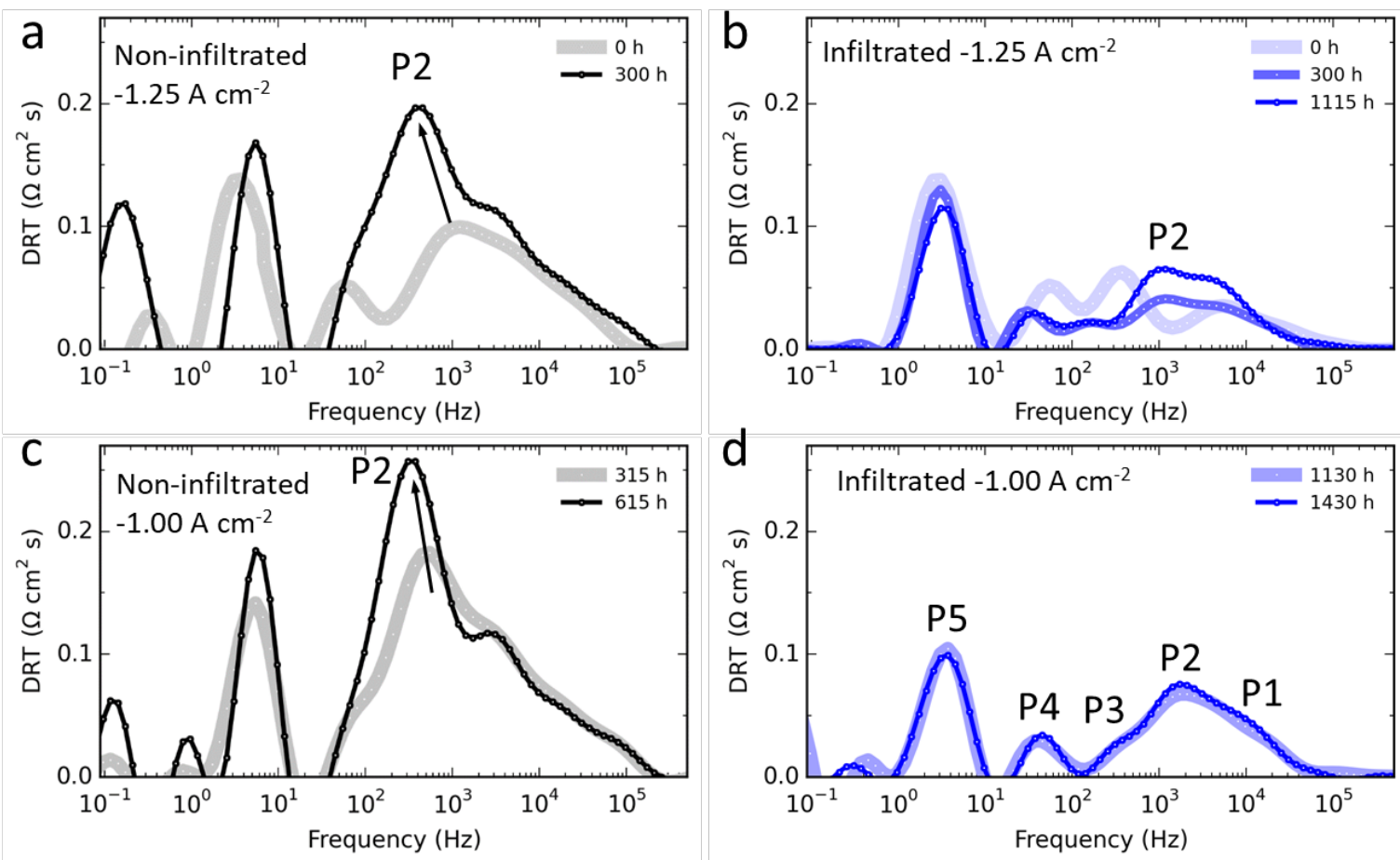

Figure 8. DRT plots of EIS data recorded under current during the durability test period. (a) $-1.25 \mathrm{~A} \mathrm{~cm}^{-2}$ on the non-infiltrated cell, (b) $-1.25 \mathrm{~A} \mathrm{~cm}^{-2}$ on the infiltrated cell, (c) $-1.00 \mathrm{~A}$ $\mathrm{cm}^{-2}$ on the non-infiltrated cell, and (d) $-1.00 \mathrm{~A} \mathrm{~cm}^{-2}$ on the infiltrated cell. 

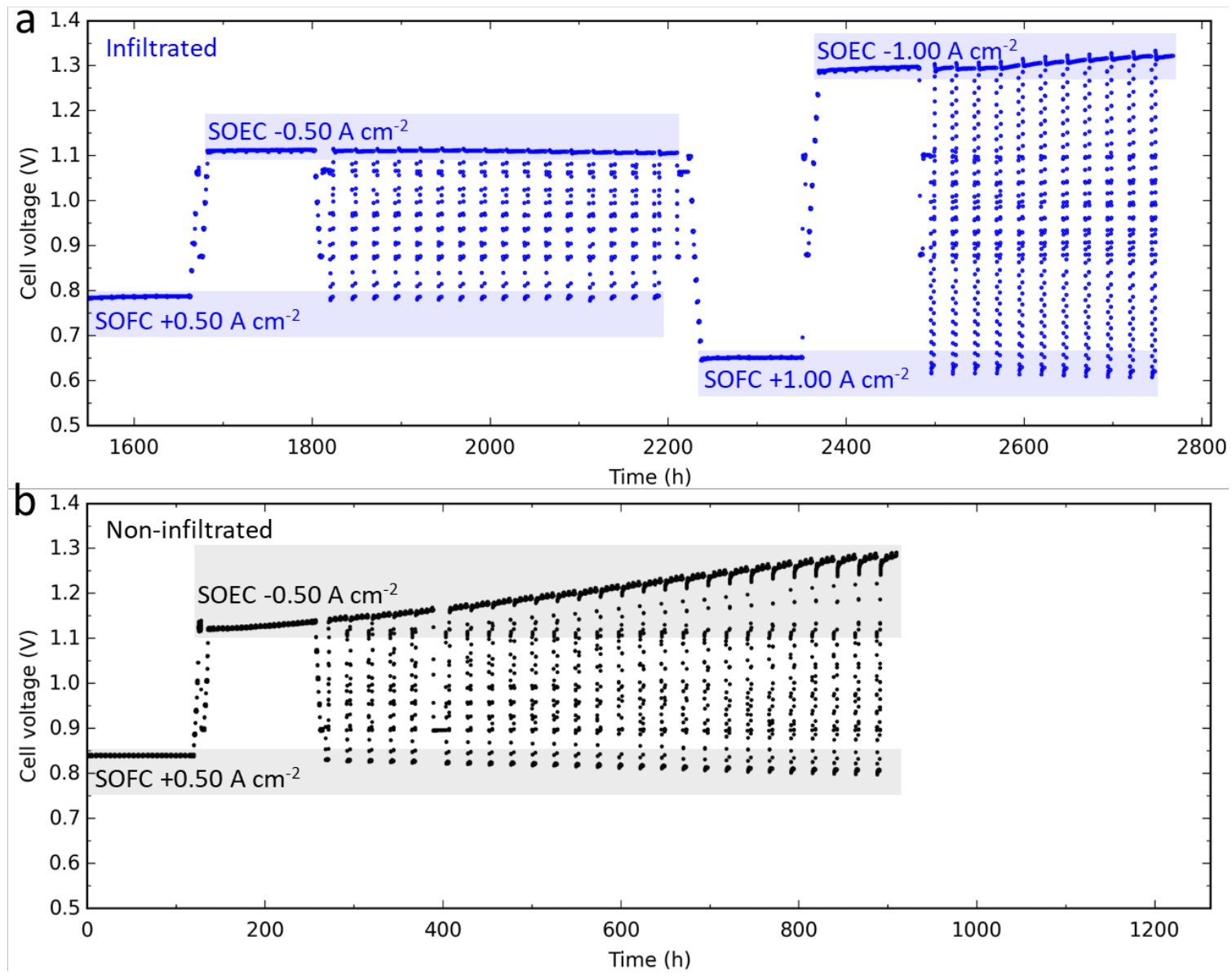

Figure 9. Comparison of the cell durability during reversible operation at $750{ }^{\circ} \mathrm{C}$. Evolution of cell voltage as a function of time on (a) infiltrated cell and (b) non-infiltrated cell. When operated at $+0.50 \mathrm{~A} \mathrm{~cm}^{-2}$ (fuel cell mode), the fuel and oxygen electrodes were fed with 12.81 $\mathrm{h}^{-1}$ of $50 \% \mathrm{H}_{2}-50 \% \mathrm{~N}_{2}$ and $601 \mathrm{~h}^{-1}$ of dry air, respectively. When operated at $-0.50 \mathrm{~A} \mathrm{~cm}^{-2}$ (electrolysis mode), the fuel and oxygen electrodes were fed with $8.01 \mathrm{~h}^{-1}$ of $80 \% \mathrm{H}_{2} \mathrm{O}-20 \% \mathrm{H}_{2}$ and $121 \mathrm{~h}^{-1}$ of dry air, respectively. For $+/-1.00 \mathrm{~A} \mathrm{~cm}^{-2}$, the composition of gas feeds was the same as that of $+/-0.50 \mathrm{~A} \mathrm{~cm}^{-2}$ but with a doubled flow rate. 